\title{
Waste Characteristics of the Former S-3 Ponds and Outline of Uranium Chemistry Relevant to NABIR Field Research Center Studies
}

\section{MARCH 2001}

Prepared by

Scott C. Brooks

Environmental Sciences Division

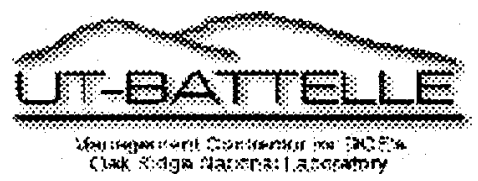




\section{DOCUMENT AVAILABILITY}

Reports produced after January 1,1996, are generally available free via the U.S. Department of Energy (DOE) Information Bridge.

Web site http://www.osti.gov/bridge

Reports produced before January 1,1996 , may be purchased by members of the public from the following source.

National Technical Information Service

5285 Port Royal Road

Springfield, VA 22161

Telephone 703-605-6000 (1-800-553-6847)

TDD 703-487-4639

Fax703-605-6900

E-mail info@ntis.fedworld.gov

Web site http://www.ntis.gov/support/ordernowabout.htm

Reports are available to DOE employees, DOE contractors. Energy Technology Data Exchange (ETDE) representatives, and International Nuclear Information System (INIS) representatives from the following source.

Office of Scientific and Technical Information

P.O. Box 62

Oak Ridge, TN 37831

Telephone 865-576-8401

Fax 865-576-5728

E-mail reports@adonis.osti.gov

Web site http://www.osti.gov/contact.html

This report was prepared as an account of work sponsored by an agency of the United States Government. Neither the United States government nor any agency thereof, nor any of their employees, makes any warranty, express or implied, or assumes any legal liability or responsibility for the accuracy, completeness, or usefulness of any information, apparatus, product, or process disclosed, or represents that its use would not infringe privately owned rights. Reference herein to any specific commercial product, process, or service by trade name, trademark, manufacturer, or otherwise, does not necessarily constitute or imply its endorsement. recommendation, or favoring by the United States Government or any agency thereof. The views and opinions of authors expressed herein do not necessarily state or reflect those of the United States Government or any agency thereof. 
ORNL/TM-2001/27

\section{WASTE CHARACTERISTICS OF THE FORMER S-3 PONDS AND OUTLINE OF URANIUM CHEMISTRY RELEVANT TO NABIR FIELD RESEARCH CENTẸR STUDIES}

Scott C. Brooks

March 2001

Prepared by

OAK RIDGE NATIONAL LABORATORY

P.O. Box 2008

Oak Ridge, Tennessee 3783 1-6285

managed by

UT-Battelle, LLC

$f \begin{array}{llllllll} & \mathrm{r} & \mathrm{t} & \mathrm{h} & \mathrm{e}\end{array}$

U.S. DEPARTMENT OF ENERGY

under contract DE-AC05-00OR22725 


\section{CONTENTS}

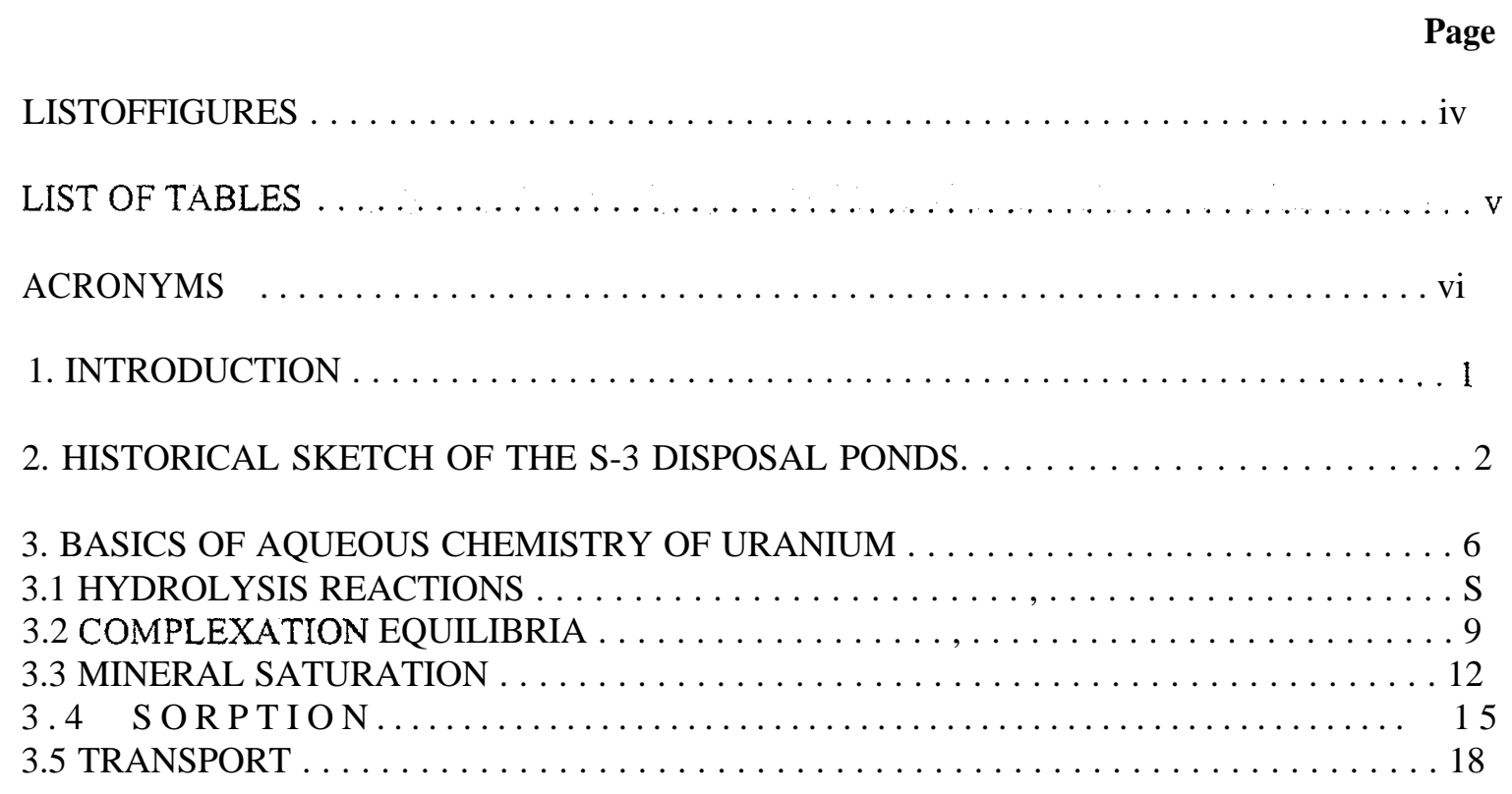

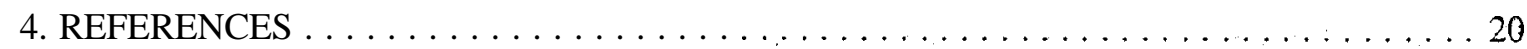




\section{LIST OF FIGURES}

Figure Page

3.1. Aqueous uranium speciation as a function of $\mathrm{pH} . \ldots \ldots \ldots \ldots \ldots \ldots \ldots \ldots \ldots$

3.2. Uranium aqueous speciation as a function of $\mathrm{pH}$ considering both hydrolysis products

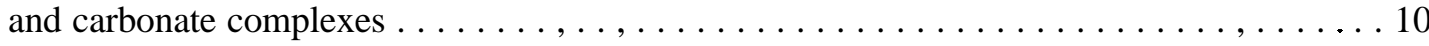

3.3. Saturation index as a function of $\mathrm{P}_{\mathrm{CO} 2}$ and $\mathrm{pH}$ with respect to $(\mathrm{A}) \hat{\mathrm{a}}-\mathrm{UO}_{2}(\mathrm{OH})_{2}$,

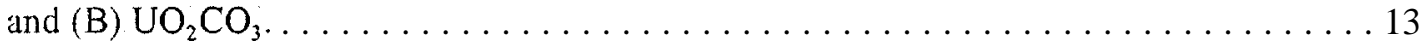

3.4. Saturation index with respect to $\hat{a}-\mathrm{UO}_{2}(\mathrm{OH})_{2}$ as a function of $\mathrm{P}_{\mathrm{CO} 2}$ for well $\mathrm{GW}-83.5 \ldots \ldots 14$

3.5. Fraction U(VI) sorbed to solid phase as a function of $\mathrm{pH}$ and $\mathrm{P}_{\mathrm{CO}_{2}} \ldots \ldots \ldots \ldots \ldots \ldots, 16$

3.6. Uranium sorption isotherms at different $\mathbf{P}_{\mathrm{CO} 2}$ levels using a surface complexation

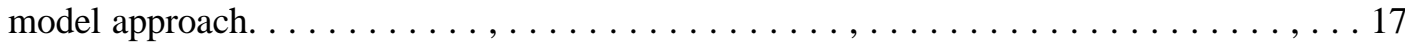

3.7. Uranium breakthrough curves (relative concentration versus dimensionless time expressed as pore volumes) at different $P_{\mathrm{CO} 2}$ values. . . . . . . . . . . . . . . . . . . . 19 


\section{LIST OF TABLES}

Table

Page

2.1. Chemical analyses of the liquid wastes collected from the S-3 disposal ponds, $1978 \ldots \ldots \ldots 2$

2.2. Chemical analyses of sludges from the $S-3$ disposal ponds, $1983 \ldots \ldots \ldots \ldots \ldots$

2.3. Total nitrate content of the $S-3$ disposal ponds by year $\ldots \ldots \ldots \ldots \ldots \ldots \ldots$

3.1 Thermodynamic constants used in geochemical modeling $\ldots \ldots \ldots \ldots \ldots, \ldots \ldots \ldots 7$

3.2. Influence of $\mathrm{P}_{\mathrm{CO} 2}$ on $\mathrm{U}(\mathrm{VI})$ transport as indicated by $\mathrm{U}$ retardation factor. . . . . . . . 18 


\section{ACRONYMS}

$\begin{array}{ll}\text { DOE } & \text { Department of Energy } \\ \text { FRC } & \text { Field Research Center } \\ \text { IAP } & \text { ion activity product } \\ \text { NABIR } & \text { Natural and Accelerated Bioremediation } \\ \text { ORNL } & \text { Oak Ridge National Laboratory } \\ \text { PI } & \text { principal investigator } \\ \text { SCM } & \text { surface complexation modeling } \\ \text { SI } & \text { saturation index } \\ \text { U } & \text { uranium }\end{array}$




\section{INTRODUCTION}

The Environmental Sciences Division at Oak Ridge National Laboratory (ORNL) was awarded the first Naturaland Accelerated Bioremediation Research (NABIR) Program, Field Research Cent\& (FRC) based upon the recommendation of a review panel following a competitive peer-reviewed proposal process. The contaminated FRC site at ORNL is centered on groundwater plumes that originate from the former S-3 Waste Disposal Ponds located at the Y- 12 Plant and the Y- 12 Bone Yard/ Bum Yard. Proposals for individual science research projects at the FRC were submitted in the spring of 2000 in response to a solicitation issued by the Department of Energy (DOE). Proposals selected for funding began work in Fiscal Year 2001 (October 1, 2000). The FRC staff have initiated several characterization efforts intended to support, inform, and educate individual FRC investigators, NABIR principal investigators (PIs), and the broader community of the specific conditions, opportunities, and challenges of this site. These efforts include both physical site characterization as well as numerical simulation (modeling) studies.

Geochemicalmodeling has been conducted with the goal of: (1) providing a baseline understanding of the geochemical behavior of uranium (U); (2) examining the interaction of geochemistry and uranium transport in the subsurface; (3) elucidating some potential pitfalls for researchers with respect to manipulating subsurface environments for the purpose of demonstrating bacterially induced $U$ immobilization. The geochemical modeling effort focused on using existing data and resources and did not involve the collection of new data or samples from the field site. Specifically, the following three tasks have been performed to date. (1) Searching for information on the wastes disposed in to the S-3 ponds. These data are typically found in internal technical reports at the labs and are rarely published in the peer-reviewed literature; thus, this information can be very difficult for the scientific community to access. Therefore, these searches may provide a nontrivial resource to investigators. To that end, some analytical data have already been located and the search for more data will continue. (2) Critical evaluation of thermodynamic data that are needed in the modeling calculations. (3) Generating model simulations to illustrate important aspects of U geochemistry and transport behavior in idealized solutions. This report summarizes the results of the geochemical modeling efforts . 


\section{HISTORICAL SKETCH OF THE S-3 DISPOSAL PONDS}

In 1951 , four unlined impoundments covering a total of about 1.44 ha were constructed at the western margin of the Oak Ridge Y-12 Plant in Bear Creek Valley. The impoundments were known as the S-3 ponds and each had a storage capacity of about 9.5 million liters. The ponds are no longer operational and have been covered with a multilayered Resource Conservation and Recovery Act cap and asphalt surface. The site now serves as a parking lot.

Over their 32 year operational lifetime, the S-3 ponds received liquid wastes generated from uranium operations at the Y-12 Plant, primarily acidic uranium nitrate (30\% uranium nitrate), although contributions from other processes (e.g., acid washing of metals; mop water) and liquid wastes and sludges from other sites (e.g., East Tennessee Technology Park and X-10 sites in Oak Ridge, Savannah River site, Idaho National Engineering $\mathrm{Lab}$ ) added a variety of other components to the waste stream $\left(\mathrm{Al}, \mathrm{F}, \mathrm{K}, \mathrm{SO}_{4}{ }^{2-},{ }^{99} \mathrm{Tc},{ }^{239} \mathrm{Pu}\right)$ (Tables 2.1 and 2.2). The composition of the sludges and liquids in the ponds varied from pond to pond and temporally. Nevertheless, the liquid waste in the ponds can generally be described as highly acidic (primarily nitric acid) and the major metallic constituents were calcium $(\mathrm{Ca})$, magnesium $(\mathrm{Mg})$, sodium $(\mathrm{Na})$, potassium $(\mathrm{K})$, and aluminum $(\mathrm{Al})$, with moderately high concentrations of trace metals. In 1976, a nitrate recovery and recycle system reduced nitrate discharges to the impoundments but there was no change in the amount of uranium discharged (Table 2.3).

In 1983 waste discharges to the ponds ceased and the wastes remaining in the ponds were treated in situ by neutralization and biodenitrification. After this treatment, the sludges were allowed to settle and the supematant liquid pumped off and treated for removal of organic contaminants and metals. The treated water was subsequently discharged to the East Fork Poplar Creek. Prior to tilling and capping the S-3 ponds, contaminated sludges from the "Blue Lagoons" area west of the S-3 ponds were added to the southwest pond.

Table 2.1. Chemical analyses of the iiquid wastes collected from the $\mathrm{S}-3$ disposal ponds, 1978 (all values are in $\mathrm{mg} / \mathrm{L}$, except pH.; reproduced from Jeter and Napier, 1978). Only inorganic constituents of the waste are shown.*

\begin{tabular}{|c|c|c|c|c|c|c|c|c|}
\hline & \multicolumn{2}{|c|}{ Northeast Pond } & \multicolumn{2}{|c|}{ Northwest Pond } & \multicolumn{2}{|c|}{ Southwest Pond } & \multicolumn{2}{|c|}{ Southeast Pond $\dagger$} \\
\hline & Top & Bottom & Top & Bottom & Ton & Bottom & Top & Bottom \\
\hline $\mathrm{pH}$ & 1.2 & 0.8 & 1.1 & 0.8 & 1.4 & 1.2 & 4.2 & 5.3 \\
\hline $\mathrm{Cl}^{-}$ & 2.330 & 1,641 & 1,600 & 1,003 & 687 & 789 & 207 & 286 \\
\hline$F^{-}$ & 9 & 25 & 8 & $3 !$ & 5 & 4 & 9 & 1 \\
\hline $\mathrm{NO}_{3}$ & 17,840 & 73,840 & 21.560 & 69,100 & 11,020 & 20,460 & 7,590 & 10,410 \\
\hline $\mathrm{U} \ddagger$ & 139.57 & 316.57 & 180.81 & 313. & 80.34 & 111.21 & 17.51 & 3.24 \\
\hline $\mathrm{Ag}$ & 0.6 & 1.8 & 0.5 & 1.8 & 0.2 & 0.4 & $<0.1$ & $<0.1$ \\
\hline $\mathrm{Al}$ & 1,202 & 4,522 & 1,346 & 4,858 & 668 & 1,370 & 300 & 8.5 \\
\hline As & 0.028 & 0.115 & 0.028 & 0.07 & 0.013 & 0.025 & 0.001 & 0.003 \\
\hline B & 30 & 17 & 21 & 8.1 & 8.5 & 7.1 & 2.6 & 1.6 \\
\hline
\end{tabular}


Table 2.1. (continued)

\begin{tabular}{|c|c|c|c|c|c|c|c|c|}
\hline & \multicolumn{2}{|c|}{ Northeast Pond } & \multicolumn{2}{|c|}{ Northwest Pond } & \multicolumn{2}{|c|}{ Southwest Pond } & \multicolumn{2}{|c|}{ Southeast Pond $\dagger$} \\
\hline & Top & Bottom & Top & Bottom & Ton & Bottom & Top & Bottom \\
\hline $\mathrm{Ba}$ & 0.4 & 0.7 & 0.5 & 4.4 & 0.3 & 0.7 & 0.8 & 0.5 \\
\hline $\mathrm{Ca}$ & 267 & 877 & 276 & 840 & 137 & 250 & 1,381 & 3,053 \\
\hline $\mathrm{Cd}$ & 0.7 & 158 & 08 & 5.4 & 0.4 & 2.0 & 0.3 & 0.7 \\
\hline $\mathrm{CO}$ & 0.5 & 1.1 & 0.5 & 1.4 & 0.4 & 0.5 . & 0.2 & 0.4 \\
\hline $\mathrm{Cr}$ & 60 & 37 & 43 & 34 & 11.9 & 11.6 & 8.5 & $<0.1$ \\
\hline $\mathrm{Cu}$ & 13.2 & 44 & 12.8 & 32 & 6.0 & 10.5 & 3.9 & 0.3 \\
\hline $\mathrm{Fe}$ & 168 & 765 & 174 & 1208 & 88 & 347 & 0.8 & 1.8 \\
\hline $\mathrm{Hg}$ & 0.052 & 0.320 & 0.062 & 0.24 & 0.032 & 0.064 & 0.004 & 0.003 \\
\hline$K$ & 90 & 310 & 86 & 416 & 43 & 109 & 93 & 98 \\
\hline $\mathbf{L i}$ & 12 & 32 & 9.5 & 25 & 4.1 & 7.9 & 5.1 & 6.9 \\
\hline $\mathrm{Mg}$ & 169 & 654 & 198 & 672 & 99 & 199 & 125 & 190 \\
\hline $\mathrm{Mn}$ & 7.5 & 24 & 9.1 & 22 & 5.2 & 11 & 8.3 & 12 \\
\hline $\mathrm{Na}$ & 3.475 & 2,300 & 2,617 & 1,128 & 1,234 & 1,262 & 652 & 664 \\
\hline $\mathrm{Ni}$ & 55 & 128 & 47 & 50 & 22 & 31 & 16 & 39 \\
\hline$P$ & 59 & 101 & 49 & 70 & 21 & 27 & 1.0 & $<0.1$ \\
\hline $\mathrm{Se}$ & 0.018 & 0.003 & 0.033 & & 0.029 & 0.022 & 0.005 & 0.002 \\
\hline $\mathrm{Si}$ & 32 & 70 & 33 & 94 & $<1$ & 51 & $<1.0$ & $<1.0$ \\
\hline $\mathrm{Sr}$ & 1.0 & 3.7 & 1.2 & 4.9 & 0.6 & 1.2 & 1.2 & 1.1 \\
\hline Th & 20 & 85 & 26 & 118 & 138 & & 0.2 & 0.1 \\
\hline $\mathrm{Ti}$ & 2.0 & 6.4 & 2.2 & 70 & 1.0 & 1.4 & $<0.1$ & $<0.1$ \\
\hline $\mathrm{Y}$ & $<0.1$ & 0.3 & 0.1 & 0.2 & $<0.1$ & $<0.1$ & $<0.1$ & $<0.1$ \\
\hline $\mathrm{Zn}$ & 8.5 & 12 & 5.6 & 10 & 2.2 & 4.0 & 1.9 & 1.4 \\
\hline $\mathrm{Zr}$ & 2.0 & 8.0 & 2.5 & 11 & 1.2 & 2.7 & $<0.1$ & $<0.1$ \\
\hline
\end{tabular}

* Waste discharges into the S-3 ponds entered in the Northeast cell and proceeded sequentlally via overflow conduits to the Northwest, Southwest, and Southeast cells. Apparently, samples were not analyzed for sulfate: later characterization of the sludges indicated sulfate concentrations of about $2000 \mathrm{mg} / \mathrm{kg}$.

$\dagger$ After 1975, the Southeast cell was used to dispose of biodenitrification sludge and alkaline waste $(\mathrm{CaCO}$ and $\mathrm{KOH})$. Between 1975 and 1978 , the $\mathrm{pH}$ in this pond increased from 0.8 to 4.8 .

$\pm 99.67 \% 23 \mathrm{U}$ 
Table 2.2. Chemical analyses of sludges from the S-3 disposal ponds, 1983 (all values are in $\mu$ g/gram dry weight; reproduced from report $\mathrm{Y} / \mathrm{MA}-6400,1983)$. Only inorganic constituents are shown.*

\begin{tabular}{|c|c|c|c|c|}
\hline & Northeast Pond & Northwest Pond & Southwest Pond & Southeast Pond $\dagger$ \\
\hline $\mathrm{Ag}$ & 17.0 & 4.1 & 2.1 & 7.3 \\
\hline $\mathrm{Al}$ & $41,854.0$ & $24,643.8$ & $59,034.9$ & $41,897.8$ \\
\hline As & 32.5 & 21.7 & 26.0 & 14.8 \\
\hline B & 98.7 & 55.7 & 138.6 & 70.0 \\
\hline $\mathrm{Ba}$ & 428.6 & 337.3 & 285.9 & 359.4 \\
\hline $\mathrm{Be}$ & 1.3 & 1.4 & 2.9 & 16.4 \\
\hline $\mathrm{Ca}$ & $1,005.5$ & 894.3 & $1,952.2$ & $3,962.9$ \\
\hline $\mathrm{Cd}$ & $<0.6$ & $<0.6$ & $<0.6$ & $<0.6$ \\
\hline $\mathrm{Ce}$ & 45.9 & 72.3 & 73.3 & 48.0 \\
\hline $\mathrm{C}_{0}$ & 1.6 & $<n .01$ & 1.4 & 3.3 \\
\hline $\mathrm{Cr}$ & 75.9 & 48.5 & 135.1 & 163.9 \\
\hline $\mathrm{Cu}$ & 136.4 & 128.2 & 111.1 & 145.3 \\
\hline $\mathrm{Fe}$ & $89,500.0$ & $8,232.8$ & $26,284.2$ & $92,031.0$ \\
\hline $\mathrm{Ga}$ & 1.6 & 30.5 & 33.5 & 11.9 \\
\hline $\mathrm{Hf}$ & 4.9 & 14.0 & 14.3 & 19.4 \\
\hline $\mathrm{Hg}$ & 1.7 & 0.21 & 0.88 & 12.0 \\
\hline $\mathrm{K}$ & $11,070.6$ & $8,307.9$ & $23,762.6$ & $8,000.3$ \\
\hline $\mathrm{La}$ & 37.7 & 45.7 & 42.1 & 25.5 \\
\hline $\mathrm{Li}$ & 46.9 & 29.2 & 35.1 & 46.3 \\
\hline $\mathrm{Mg}$ & 2.614 .7 & $1,593.7$ & $4,437.0$ & $2,341.1$ \\
\hline $\mathrm{Mn}$ & 108.1 & 45.9 & 63.1 & 112.0 \\
\hline Mo & 103.8 & 30.1 & 113.7 & 191.7 \\
\hline $\mathrm{Na}$ & 1.768 .9 & $2,041.0$ & $1,993.5$ & $1,429.5$ \\
\hline $\mathrm{Nb}$ & 62.0 & 45.6 & 30.9 & 136.8 \\
\hline $\mathrm{Ni}$ & 73.9 & 62.9 & 60.6 & 98.8 \\
\hline $\mathbf{P}$ & $1,333.5$ & $2,296.9$ & $2,454.8$ & $6,896.4$ \\
\hline $\mathrm{Pb}$ & 198.1 & 207.0 & 155.0 & 119.7 \\
\hline
\end{tabular}


Table 2.2 (continued)

\begin{tabular}{|l||l|l|l|l|}
\hline & Northeast Pond & Northwest Pond & Southwest Pond & Southeast Pond $\dagger$ \\
\hline $\mathrm{Sc}$ & 8.1 & 4.6 & 8.4 & 5.6 \\
\hline $\mathrm{Se}$ & $<0.2$ & $<0.2$ & $<0.2$ & $<0.2$ \\
\hline $\mathrm{Si}$ & 37.5 & 22.7 & 666.0 & 40.9 \\
\hline $\mathrm{Sr}$ & 46.0 & 66.5 & 62.3 & 40.3 \\
\hline $\mathrm{Th}$ & 150.0 & 529.4 & 196.0 & 271.7 \\
\hline $\mathrm{Ti}$ & $5,172.1$ & $5,206.1$ & $5,120.1$ & $3,630.5$ \\
\hline $\mathrm{U} \ddagger$ & 280.0 & 300.0 & 410.0 & 620.0 \\
\hline $\mathrm{V}$ & 61.5 & 26.5 & 64.7 & 63.1 \\
\hline $\mathrm{Y}$ & 12.5 & 11.6 & 12.1 & 8.4 \\
\hline $\mathrm{Zn}$ & 95.0 & 34.0 & 56.3 & 91.2 \\
\hline $\mathrm{Zr}$ & 817.7 & 3.366 .0 & $1,077.4$ & $1,472.0$ \\
\hline
\end{tabular}

* Waste discharges into the S-3 ponds entered in the Northeast cell and proceeded sequentially via overflow conduits to the Northwest, Southwest, and Southeast cells. Apparently, samples were not analyzed for sulfate: later characterization of the sludges indicated sulfate concentrations of about $2,000 \mathrm{mg} / \mathrm{kg}$.

+ After 1975, the Southeast cell was used to dispose of biodenitrification sludge and alkaline waste $(\mathrm{CaCO} ;$ and $\mathrm{KOH})$. Between 1975 and 1978 , the $\mathrm{pH}$ in this pond increased from 0.8 to 4.8 .

$\ddagger 99.5 \% 238 \mathrm{U}$

Table 2.3. Total nitrate content of the $S-3$ disposal ponds by year*

\begin{tabular}{c|c}
\hline Year & Nitrate Content (kg) \\
\hline 1962 & 2263000 \\
\hline 1975 & 1866000 \\
\hline 1978 & 993000 \\
\hline 1981 & 581000 \\
\hline 1983 & 978000 \\
\hline
\end{tabular}

*Reproduced from report Y/MA-6400, 1983. 


\section{BASICS OF AQUEOUS CHEMISTRY OF URANIUM}

Uranium contamination of soils and groundwater surrounding the S-3 ponds is one of the drivers demanding remedial action at the FRC site. Areas near the ponds were contaminated due to the nature of both the ponds (seepage ponds) and the wastes. The appearance of uranium farther away from the ponds results from interaction of the intruding waste with resident fluids, soil and aquifer minerals, and solute transport. The geochemistry of uranium and the reactions of the waste with soil and aquifer minerals, coupled with the site hydrology, can be used to understand what factors contribute to the movement of this solute in groundwater at the FRC site. Part of the reason uranium has moved down the valley lies in the physical hydrology of the system (rapid flow through conductive fracture networlc). In this report we examine several chemical processes that influence uranium transport: hydrolysis, complexation equilibria, and sorption. Sorption serves as a mechanism to reduce uranium mobility (ignoring sorption to mobile colloids for the sake of simplicity). Hydrolysis and aqueous complexation change the charge and composition of uranium in solution and may increase uranium solubility, decreasing the effectiveness of sorptive mechanisms in slowing the movement of uranium.,

Another mechanism that can remove $U$ from solution and slow its movement in groundwater is precipitation. Recent work has suggested that at $\mathrm{U}$ concentrations $\sim 10^{-9} \mathrm{M}$ the time scale for uranium precipitation in groundwater systems is on the order of centuries (Luw et al., 2000). The relative importance of non-microbial uranium precipitation at the FRC site ( $\mathrm{U}$ concentrations $\sim 10^{-5} \mathrm{M}$ ) is difficult to assess without direct examination of solid phase materials. Nevertheless, most of the water analyses that were examined for this report indicated that the waters were undersaturated with respect to most uranium minerals. This observation, in conjunction with the slow kinetics of precipitation suggests that this process does not exert a major control on $\mathrm{U}$ solubility at the FRC site. For the purposes of this report, precipitation of $\mathrm{U}$ minerals was not allowed although the degree of saturation with respect to the solid phases $\beta-\mathrm{UO}_{2}(\mathrm{OH})_{2}$ and $\mathrm{UO}_{2} \mathrm{CO}_{3}$ was considered.

Some documents related to site characterization speculate that $U$ discharged to the S-3 ponds was in some combination of the IV, V, and VI oxidation states. However, neither the wastes nor the pond fluids or sludges were analyzed to determine $U$ oxidation state. Given the low solubility of U(IV) and the rapid oxidation kinetics of $U(\Gamma)$ and $U(V)$, we assume that all the $U$ is in the hexavalent state (U(VI)).

Uranium hydrolysis, aqueous complexation, precipitation, and sorption are explored below. These processes are illustrated by geochemical modeling using a fluid with $10^{-5} \mathrm{M} \mathrm{UO}_{2}{ }^{2+}$. and ionic strength $(\mathrm{I})=$ 0.2 . These values were chosen as an approximation to the water analysis data from wells in the vicinity of the S-3 ponds at the FRC site. Modeling results presented in this report may differ in specifics from other published reports that have used different modeling assumptions (e.g., different ionic strength or $\mathrm{U}_{\text {TOT }}$ ); nevertheless, the general aspects of the modeling results are similar. Thermodynamic constants used in the modeling are given in Table 3.1 below. The thermodynamic data were used for the aqueous speciation and sorption modeling in this report. The subscript "s" for the surface complexation reactions designates strong sites, whereas the subscript " $w$ " designates weak sites. Where no distinction among sites is made, the log $\mathrm{K}$ value is assumed to be the same for both strong and weak sites. 
Table 3.1 Thermodynamic constants used in geochemical modeling.

\begin{tabular}{|c|c|c|c|}
\hline \multicolumn{2}{|r|}{ Metal Hydrolysis } & $\begin{array}{c}\log \mathrm{K} \\
\left(25^{\circ} \mathrm{C}, I=0\right)\end{array}$ & Source \\
\hline 1 & $\mathrm{UO}_{2}{ }^{2+}+\mathrm{H}_{2} \mathrm{O}=\mathrm{UO}_{2} \mathrm{OH}^{+}+\mathrm{H}+$ & -5.2 & $\mathrm{a}$ \\
\hline 2 & $\mathrm{UO}_{2}{ }^{2+}+2 \mathrm{H}_{2} \mathrm{O}=\mathrm{UO}_{2}(\mathrm{OH})_{2(\mathrm{aq})}+2 \mathrm{H}^{+}$ & -10.3 & $\mathrm{a}$ \\
\hline 3 & $\mathrm{UO}_{2}^{2+}-3 \mathrm{H}_{2} \mathrm{O}=\mathrm{UO}_{2}(\mathrm{OH})_{3}^{-}+3 \mathrm{H}^{+}$ & -19.2 & $\mathrm{a}$ \\
\hline 4 & $\mathrm{UO}_{2}^{2+}+4 \mathrm{H}_{2} \mathrm{O}=\mathrm{UO}_{2}(\mathrm{OH})_{4}^{2-}+4 \mathrm{H}^{+}$ & -33.0 & a \\
\hline 5 & $2 \mathrm{UO}_{2}^{2+}-\mathrm{H}_{2} \mathrm{O}=\left(\mathrm{UO}_{2}\right)_{2} \mathrm{OH}^{3+}+\mathrm{H}^{+}$ & -2.7 & $\mathrm{a}$ \\
\hline 6 & $2 \mathrm{UO}_{2}{ }^{2+}+2 \mathrm{H}_{2} \mathrm{O}=\left(\mathrm{UO}_{2}\right)_{2}(\mathrm{OH})_{2}{ }^{2+}+2 \mathrm{H}^{+}$ & -5.62 & $\mathrm{a}$ \\
\hline 7 & $3 \mathrm{UO}_{2}^{2+}+4 \mathrm{H}_{2} \mathrm{O}=\left(\mathrm{UO}_{2}\right)_{3}(\mathrm{OH})_{4}^{2+}+4 \mathrm{H}^{+}$ & -11.9 & $\mathrm{a}$ \\
\hline 8 & $3 \mathrm{UO}_{2}^{2+}+5 \mathrm{H}_{2} \mathrm{O}=\left(\mathrm{UO}_{2}\right)_{3}(\mathrm{OH})_{5}^{+}+5 \mathrm{H}^{+}$ & -15.5 & $\mathrm{a}$ \\
\hline 9 & $2 \mathrm{UO}_{2}^{2++}+7 \mathrm{H}_{2} \mathrm{O}=\left(\mathrm{UO}_{2}\right)_{3}(\mathrm{OH})_{7}^{+}+7 \mathrm{H}^{+}$ & -31.0 & $\mathrm{a}$ \\
\hline \multicolumn{4}{|c|}{ Carbonate Complexes } \\
\hline 10 & $\mathrm{UO}_{2}{ }^{2+}+\mathrm{CO}_{3}{ }^{2-}=\mathrm{UO}_{2} \mathrm{CO}_{3(\mathrm{aq})}$ & 9.68 & $\mathrm{a}$ \\
\hline 11 & uo $\frac{2}{2}+2 \mathrm{CO}_{3}^{2-}=\mathrm{UO}_{2}\left(\mathrm{CO}_{3}\right)_{2}^{2-}$ & 16.94 & $\mathrm{a}$ \\
\hline 12 & $\mathrm{UO}_{2}{ }^{2+}+3 \mathrm{CO}_{3}^{2+}=\mathrm{UO}_{2}\left(\mathrm{CO}_{3}\right)_{3}^{4-}$ & 21.6 & a \\
\hline 13 & $3 \mathrm{UO}_{2}{ }^{2+}+6 \mathrm{CO}_{3}^{2-}=\left(\mathrm{UO}_{2}\right)_{3}\left(\mathrm{CO}_{3}\right)_{6}^{6-}$ & 54.0 & $\mathrm{a}$ \\
\hline 14 & $2 \mathrm{UO}_{2}{ }^{2+}+4 \mathrm{H}_{2} \mathrm{O}+\mathrm{CO}_{2(\mathrm{~g})}=\left(\mathrm{UO}_{2}\right)_{2} \mathrm{CO}_{3}(\mathrm{OH})_{3}{ }^{-}+5 \mathrm{H}^{+}$ & -19.01 & $\mathrm{a}$ \\
\hline \multicolumn{4}{|c|}{ olid Phases } \\
\hline 15 & $\beta-\mathrm{UO}_{2}(\mathrm{OH})_{2(\mathrm{~s})}+2 \mathrm{H}^{+}=\mathrm{UO}_{2}{ }^{2+}+2 \mathrm{H}_{2} \mathrm{O}$ & 4.93 & $a^{*}$ \\
\hline 16 & $\mathrm{UO}_{2} \mathrm{CO}_{3}=\mathrm{UO}_{2}^{2+}+\mathrm{CO}_{3}^{2-}$ & -14.47 & $\mathrm{a}$ \\
\hline \multicolumn{4}{|c|}{ Surface Protonation Reactions } \\
\hline 17 & $>\mathrm{FeOH}-\mathrm{H}^{+}=>\mathrm{FeOH}_{2}^{+}$ & 6.51 & $\mathrm{~b}$ \\
\hline 18 & $>\mathrm{FeOH}=\mathrm{FeO}-+\mathrm{H}^{+}$ & -9.13 & $\mathrm{~b}$ \\
\hline \multicolumn{4}{|c|}{ Surface Complexation Reactions } \\
\hline 19 & $\left(>\mathrm{Fe}_{s}(\mathrm{OH})_{2}\right)+\mathrm{UO}_{2}^{2+}=\left(>\mathrm{Fe}_{s} \mathrm{O}_{2}\right) \mathrm{UO}_{2}+2 \mathrm{H}^{+}$ & -2.57 & $\mathrm{~b}$ \\
\hline 20 & $\left(>\mathrm{Fe}_{\mathrm{w}}(\mathrm{OH})_{2}\right)+\mathrm{UO}_{2}^{2+}=\left(>\mathrm{Fe}_{\mathrm{w}} \mathrm{O}_{2}\right) \mathrm{UO}_{2}+2 \mathrm{H}^{+}$ & -6.28 & $\mathrm{~b}$ \\
\hline 21 & $>\mathrm{FeOH}-\mathrm{H}_{2} \mathrm{CO}_{3}=>\mathrm{FeCO}_{3} \mathrm{H}+\mathrm{H}_{2} \mathrm{O}$ & 2.90 & $\mathrm{~b}$ \\
\hline 22 & $>\mathrm{FeOH}-\mathrm{H}_{2} \mathrm{CO}_{3}=>\mathrm{FeCO}_{3}^{-}+\mathrm{H}_{2} \mathrm{O}+\mathrm{H}^{+}$ & -5.09 & $\mathrm{~b}$ \\
\hline 23 & $\left(>\mathrm{Fe}_{s}(\mathrm{OH})_{2}\right)+\mathrm{UO}_{2}{ }^{2+}+\mathrm{CO}_{3}{ }^{2-}=\left(>\mathrm{Fe}_{\mathrm{s}} \mathrm{O}_{2}\right) \mathrm{UO}_{2} \mathrm{CO}_{3}{ }^{2-}+2 \mathrm{H}^{+}$ & 3.67 & $\mathrm{~b}$ \\
\hline 24 & $\left(>\mathrm{Fe}_{\mathrm{w}}(\mathrm{OH})_{2}\right)+\mathrm{UO}_{2}{ }^{2+}+\mathrm{CO}_{3}{ }^{2-}=\left(>\mathrm{Fe}_{\mathrm{w}} \mathrm{O}_{2}\right) \mathrm{UO}_{2} \mathrm{CO}_{3}{ }^{2-}+2 \mathrm{H}^{+}$ & -0.42 & $\mathrm{~b}$ \\
\hline
\end{tabular}

*derived from $\left\langle G_{l}{ }^{\circ}\right.$ values reported by Grenthe et al. (1992).

"Grenthe ct al., 1992.

b Waite et al., 1994. 


\subsection{HYDROLYSIS REACTIONS.}

Hydrolysis results in the formation of aqueous species and solid hydroxides by the action of water. Hydrolysis reactions thereby change the composition and net charge of the metal ion and exert solubility controls on water composition. These reactions are important for all the actinide elements. Uranyl hydrolysis can be represented generically as:

$$
\left(\mathrm{UO}_{2}^{2+}\right)_{m}+n \mathrm{H}_{2} \mathrm{O}=\left(\mathrm{UO}_{2}\right)_{m}(\mathrm{OH})_{n}^{2 m-n}+n \mathrm{H}^{+}
$$

Uranyl hydrolysis begins at about $\mathrm{pH} 3$ and these species become more important as the solution $\mathrm{pH}$ increases (Fig. 3.1) . Polymeric species ( $m>1$ in Equation (1)) become increasingly important as the total concentration of Uranium in solution increases. As indicated in Equation (1), when $n \geq 2 m$ uranium exists in solution as a neutral or negatively charged species. 


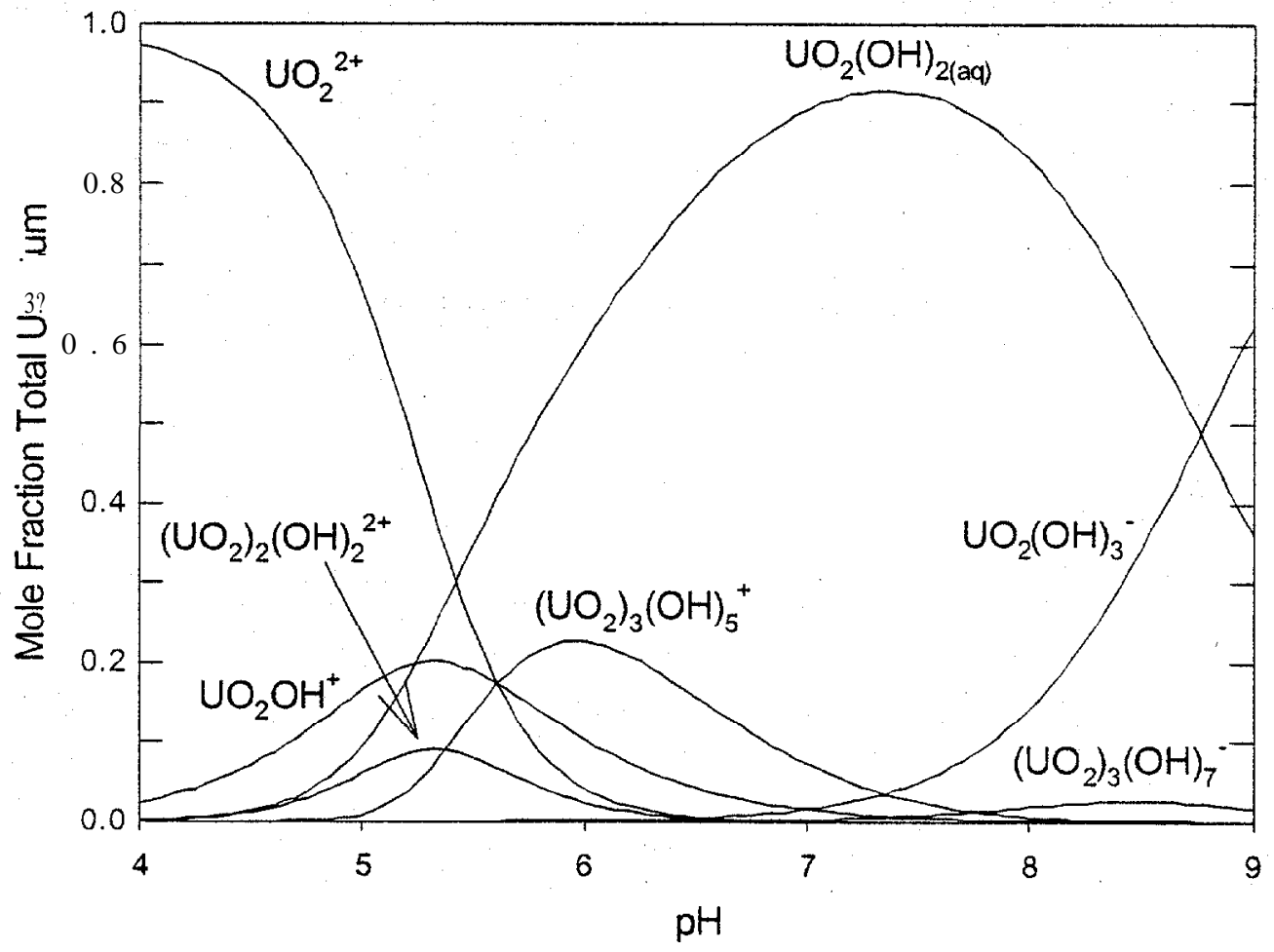

Fig. 3.1. Aqueous uranium speciation as a function of $\mathbf{p H}$. Species are plotted as the mole fraction of total uranium versus solution $\mathrm{pH}$. Only hydrolysis products were considered for this diagram. $\mathrm{U}_{\text {тот }}=10^{-5} \mathrm{M} ; \mathrm{I}=0.2$; no precipitation allowed. 


\subsection{COMPLEXATION EQUILIBRIA}

Among the most important naturally occurring complexants for uranyl ion are the carbonate species, bicarbonate $\left(\mathrm{HCO}_{3}{ }^{-}\right)$and carbonate $\left(\mathrm{CO}_{3}{ }^{2-}\right)$. These two species are present at significant concentrations in many natural waters and form very strong complexes with $\mathrm{UO}_{2}{ }^{2+}$. An understanding of this relationship led to the development of the alkali leaching process of uranium ores for the selective removal of uranium.

The S-3 ponds were excavated in saprolite which had weathered from the underlying Nolichucky shale. The Nolichucky formation has a carbonate mineral content of $11 \mathrm{wt} \%$ (Lee et al., 1987) and the overlying saprolite derived from it contains variable amounts of residual carbonate minerals. Part of the waste plume created from the S-3 wastes penetrated into the Nolichuclcy formation and has upwelled, mixing with shallower water and discharging into creeks down Bear Creek Valley. Thus, as the highly acidic waste percolated through the saprolite and the Nolichucky formation, there was ample opportunity for interaction with carbonate minerals to neutralize some of the acidity and for the fluid to accumulate dissolved inorganic carbon.

Aqueous speciation diagrams for uranium were generated assuming $\mathrm{I} 0^{-5} \mathrm{M} \mathrm{U}, \mathrm{I}=0.2 \mathrm{M}$ and maintaining equilibrium between the solution and a gas phase with fixed partial pressure of $\mathrm{CO}_{2(\mathrm{~g})}\left(\mathrm{P}_{\mathrm{CO} 2}\right)$. In different simulations, the $\mathrm{P}_{\mathrm{CO} 2}$ was fixed at atmospheric levels $\left(10^{-3.5}\right)$ or at two different elevated $\mathrm{P}_{\mathrm{CO} 2}$ levels: $10^{-2}$ or $10^{-0.757}$. The latter value was chosen based on the analysis of water samples from the FRC site. As the concentration of total inorganic carbon exceeds the concentration of $\mathrm{U}$, the carbonate species dominate $\mathrm{U}$ speciation (Fig. 3.2A-C). At high pH, hydrolysis products are no longer important. As the partial pressure of $\mathrm{CO}$, increases, the carbonate species begin to dominate at lower $\mathrm{pH}$ values (cf. Fig.. 3. $2 \mathrm{~A}-2 \mathrm{C}$ ). The results of these calculations clearly show the significant impact that carbonate complexation has on the aqueous speciation of $\mathrm{U}(\mathrm{VI})$ (Fig. 3.2A-C). The implications of these complexation reactions for uranium mobility are addressed below. 

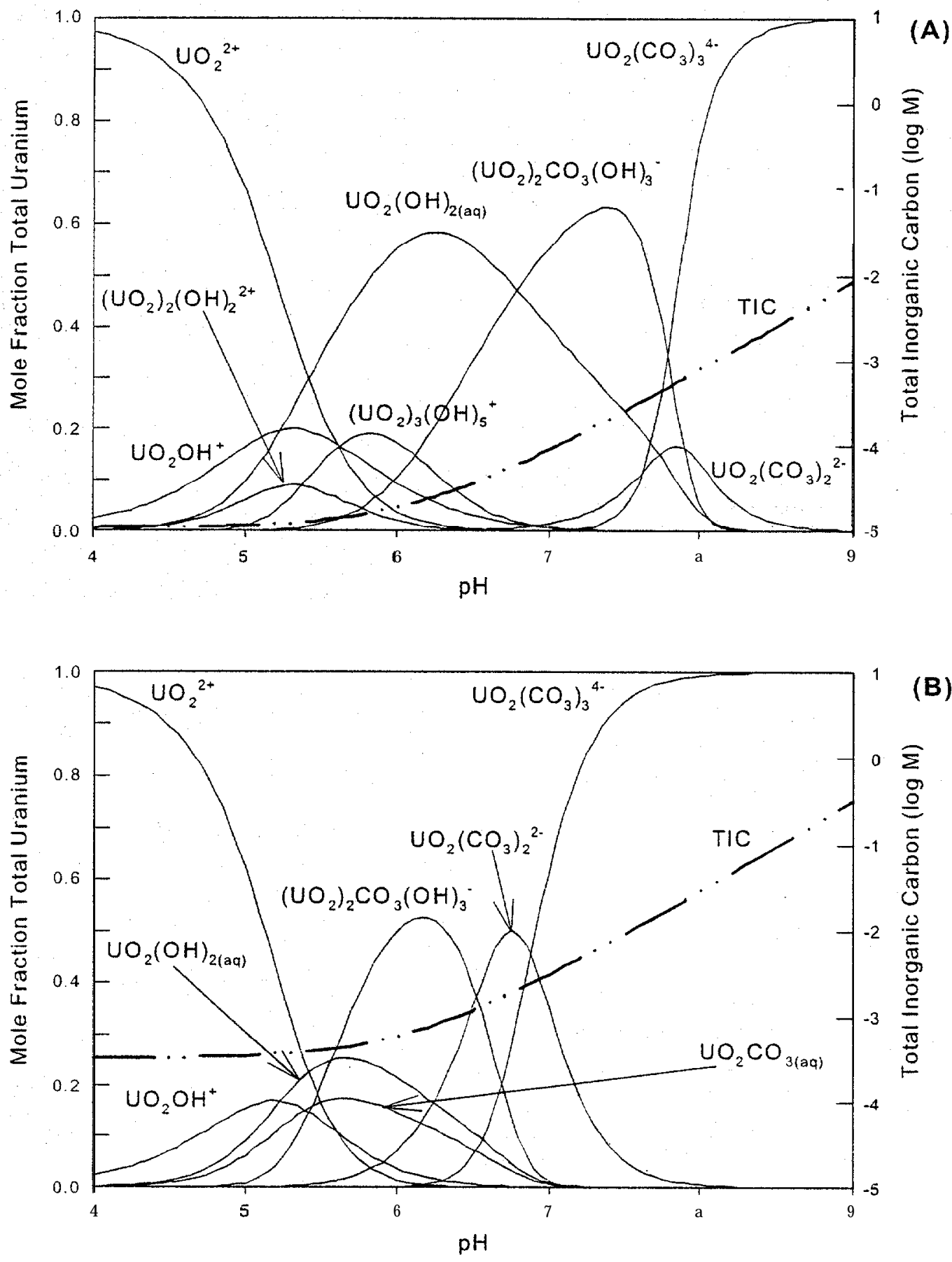

Fig.3.2. Uranium aqueous speciation as a function of $\mathrm{pH}$ considering both hydrolysis products and carbonate complexes. Species are plotted as mole fraction total uranium versus solution $\mathrm{pH}$. $\mathrm{U}_{\text {ror }}=10^{-5} \mathrm{M}: \mathrm{I}=0.1 ;$ (A) $\mathrm{P}_{\mathrm{CO} 2}=10^{-3.5}$; (B) $\mathrm{P}_{\mathrm{CO} 2}=$ $10^{-2.0}$; no precipitation allowed. 


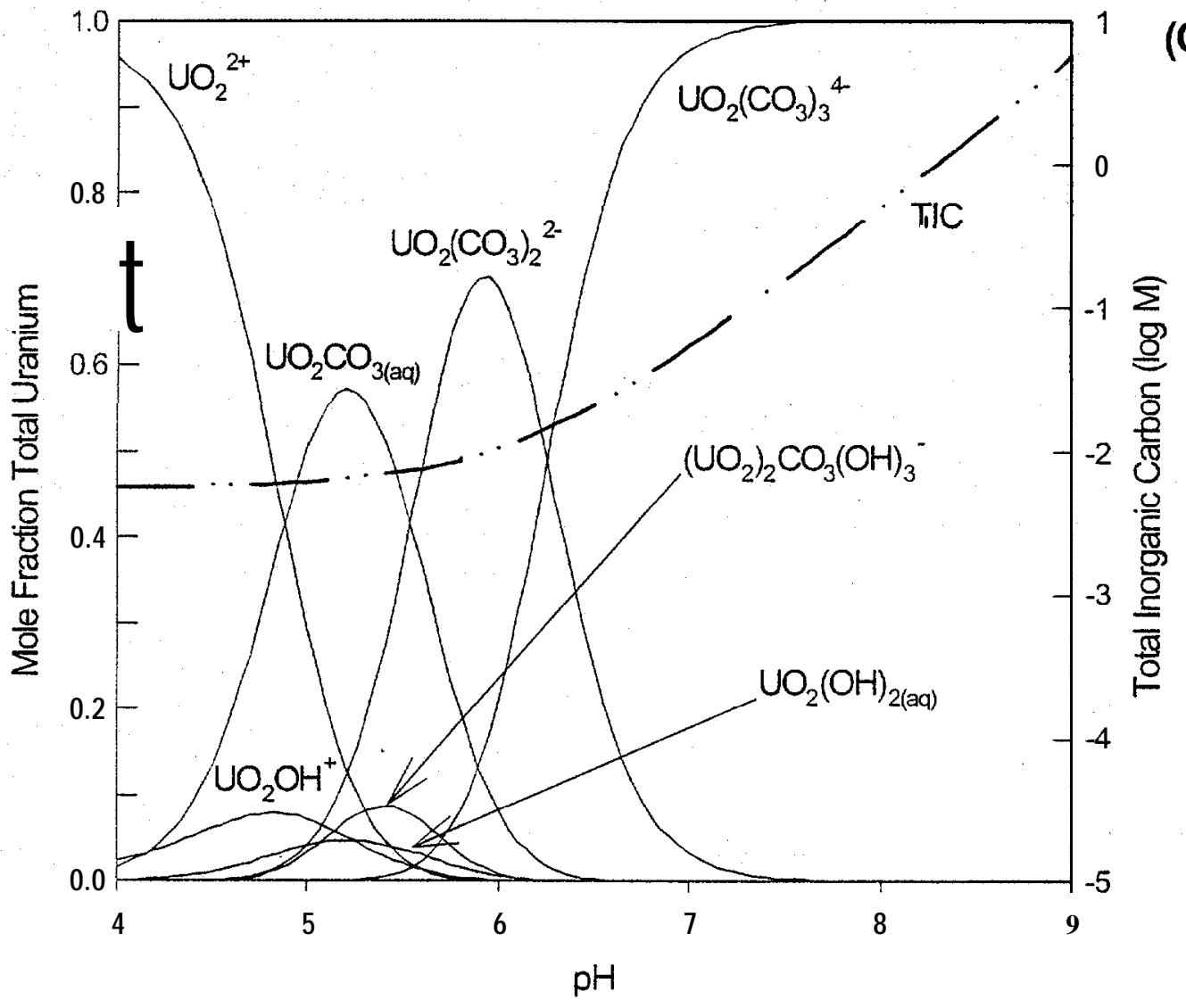

(C)

Fig. 3.2 (cont.) Uranium aqueous speciation as a function of $\mathrm{pH}$ considering both hydrolysis products and carbonate complexes (C). $U_{\mathrm{TOT}}=10^{-5} \mathrm{M} ; \mathbf{I}=\mathbf{0 . 2}$; (C) $\mathrm{P}_{\mathrm{CO} 2}=10^{-0.757}$; no precipitation allowed. 


\subsection{MINERAL SATURATION}

Given a water composition, it is possible to evaluate whether the water is over- or undersaturated with respect to various mineral phases. This state is commonly expressed in terms of the saturation index (SI) which compares the product of ion activities to the equilibrium constant for the reaction. A general form for this is:

$$
\begin{gathered}
\left(A_{a} B_{b}\right)_{\text {solid }}=a A+b B \quad K_{s p}=\frac{\tilde{\mathrm{a}}_{A}[A]^{\alpha} \tilde{\mathrm{a}}_{B}[B]^{b}}{a_{A_{a} B_{b}}} \\
I A P=\tilde{\mathrm{a}}_{A}[A]^{\alpha} \tilde{\mathrm{a}}_{B}[B]^{b} \\
S I=\log \frac{I A P}{K_{s p}}
\end{gathered}
$$

in which ion activity product (IAP) is determined from the aqueous speciation of the water; $[\mathrm{A}]=$ concentration; $\gamma_{i}=$ activity coefficient. An undersaturated mineralhas a negative SI (reaction (2) needs to proceed to the right to reach equilibrium), an oversaturated mineral has a positive SI (reaction (2) needs to proceed to the left to reach equilibrium), and a mineral in equilibrium with the water has an $\mathrm{SI}=0$.

The impact of hydrolysis and carbonate complexation on the aqueous speciation of $\mathrm{U}$ has been illustrated. For the same scenarios used above $\left(10^{-5} \mathrm{M} \mathrm{U} ; \mathrm{I}=0.2 \mathrm{M}\right)$, we can calculate the SI with respect to $\beta$ $\mathrm{UO}_{2}(\mathrm{OH})_{2}$ and $\mathrm{UO}_{2} \mathrm{CO}_{3}$ as a function of $\mathrm{pH}$. In the absence of $\mathrm{CO}$, the solution is oversaturated with respect to $\beta-\mathrm{UO}_{2}(\mathrm{OH})_{2}$ from $\mathrm{pH} 5.8$ to 8.9 (Fig. 3. 3A). Above pH 8.9, the formation of stable aqueous hydrolysis products increases the solubility of U(VI) and the SI decreases. When in equilibrium with atmospheric $\mathrm{CO}_{2}$, the fluid is oversaturated with respect to $\beta-\mathrm{UO}_{2}(\mathrm{OH})_{2}$ over a narrower $\mathrm{pH}$ range, from $\mathrm{pH}$ 5.8 to 7.1. At higher levels of $\mathrm{CO}_{2}$, the solution remains undersaturated across the range of pH (Fig. 3.3A). For all levels of $\mathrm{CO}_{2}$ examined, the solution remains undersaturated with respect $\mathrm{UO}_{2} \mathrm{CO}_{3}$ (Fig. 3.3B). The formation of stable aqueous carbonate complexes results in higher uranium solubility, making $\mathrm{U}$ precipitation less favorable (thus the use of alkali leaching to recover $\mathrm{U}$ from ore) potentially resulting in the undesirable enhanced transport of uranium.

Similar simulations were conducted for a water composition from the FRC site (well GW-83.5; $\mathrm{http} / /$ wrww.esd.ornl.gov/BCV-FieldSite/). The SI with respect to $\beta-\mathrm{UO}_{2}(\mathrm{OH})_{2}$ as a function of $\mathrm{P}_{\mathrm{CO} 2}$ was calculated. As the $\mathrm{P}_{\mathrm{CO}_{2}}$ comes into equilibrium with atmospheric $\mathrm{CO}_{2}$, the water becomes over-saturated with respect to this mineral phase (Fig. 3.4). Field projects at the FRC propose to withdraw groundwater, make various amendments to promote bacterial activity in the aquifer, and reinject the water. Significant loss of $\mathrm{CO}$, during these pumping operations may lead to the precipitation of U(VI) solids in the equipment or possibly the reinjection of U(VI) colloids complicating the bioreduction efforts and interpretation of results. 


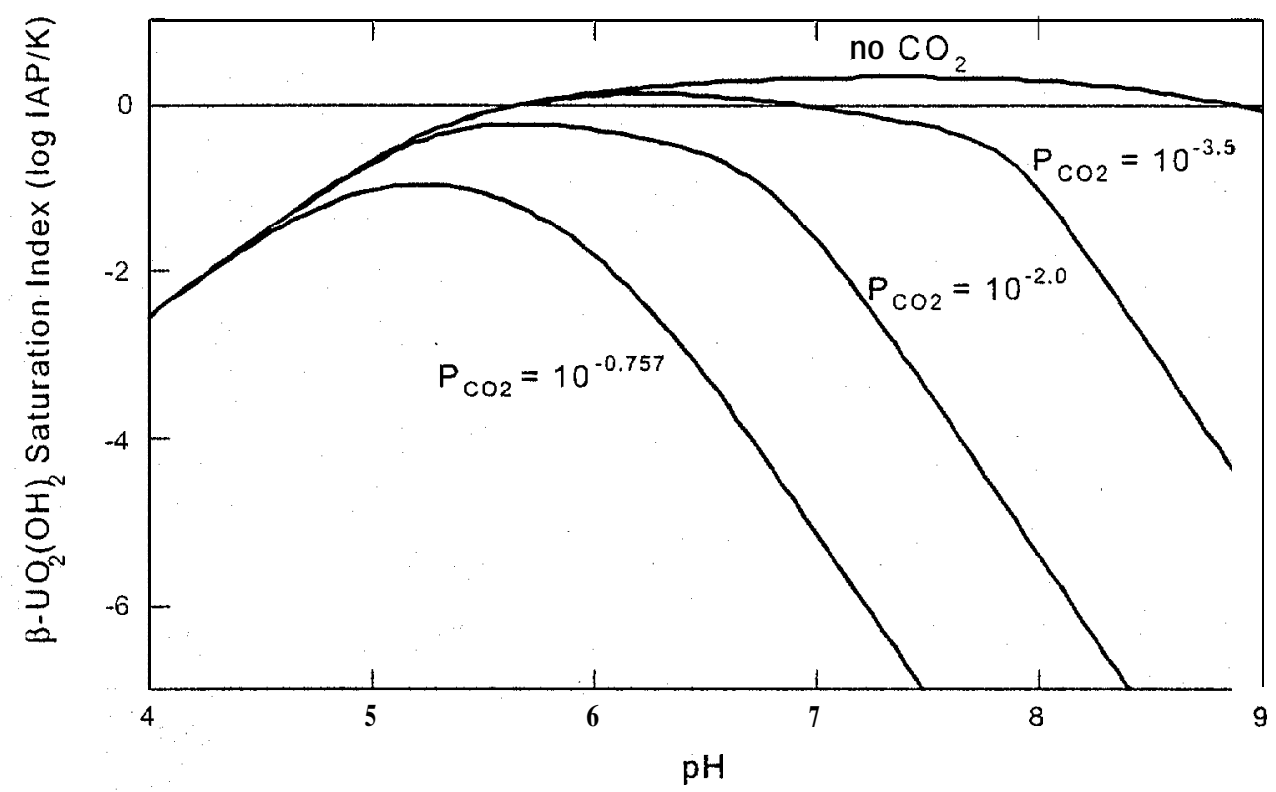

(A)

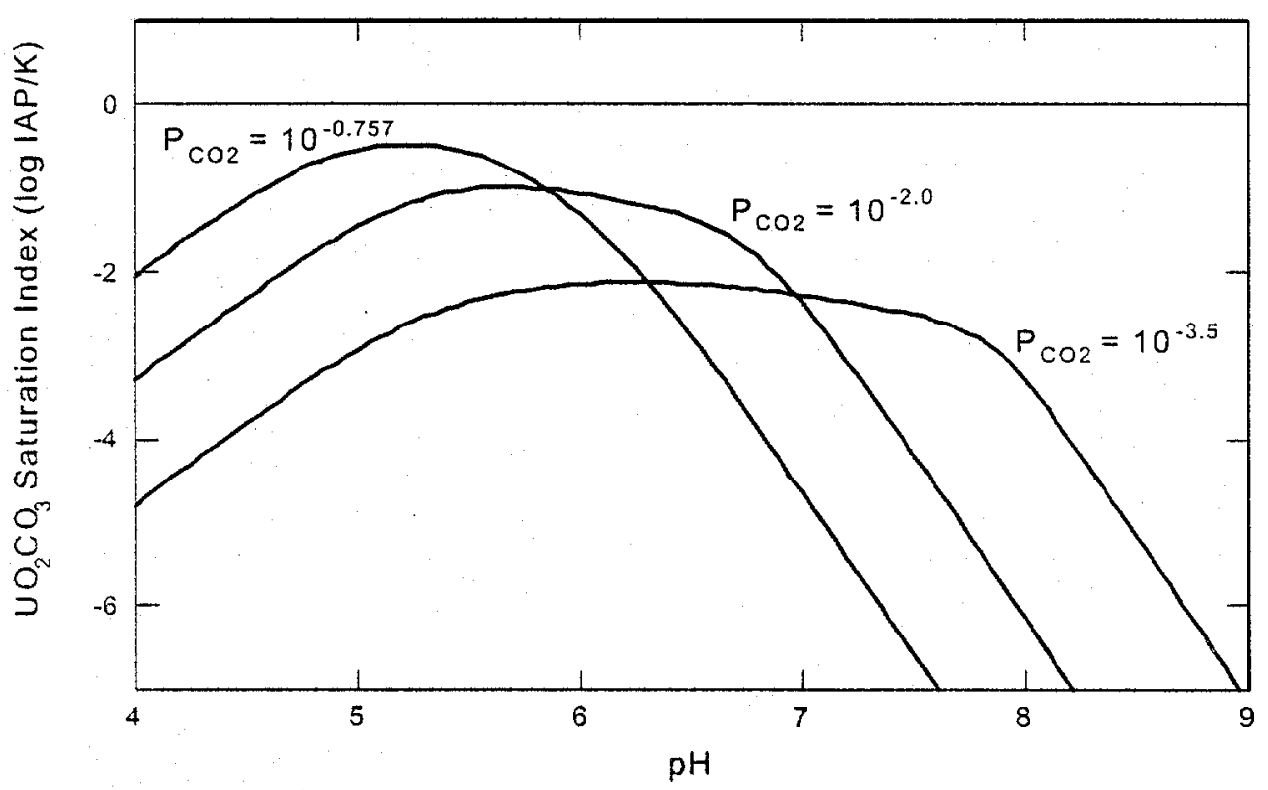

(B)

Fig. 3.3. Saturation index as a function of $\mathrm{P}_{\mathrm{CO} 2}$ and $\mathrm{pH}$ with respect to $(\mathrm{A}) \mathrm{\beta}-\mathrm{UO}_{2}(\mathrm{OH})_{2}$, and (B) $\mathrm{UO}_{2} \mathrm{CO}_{3}$. 


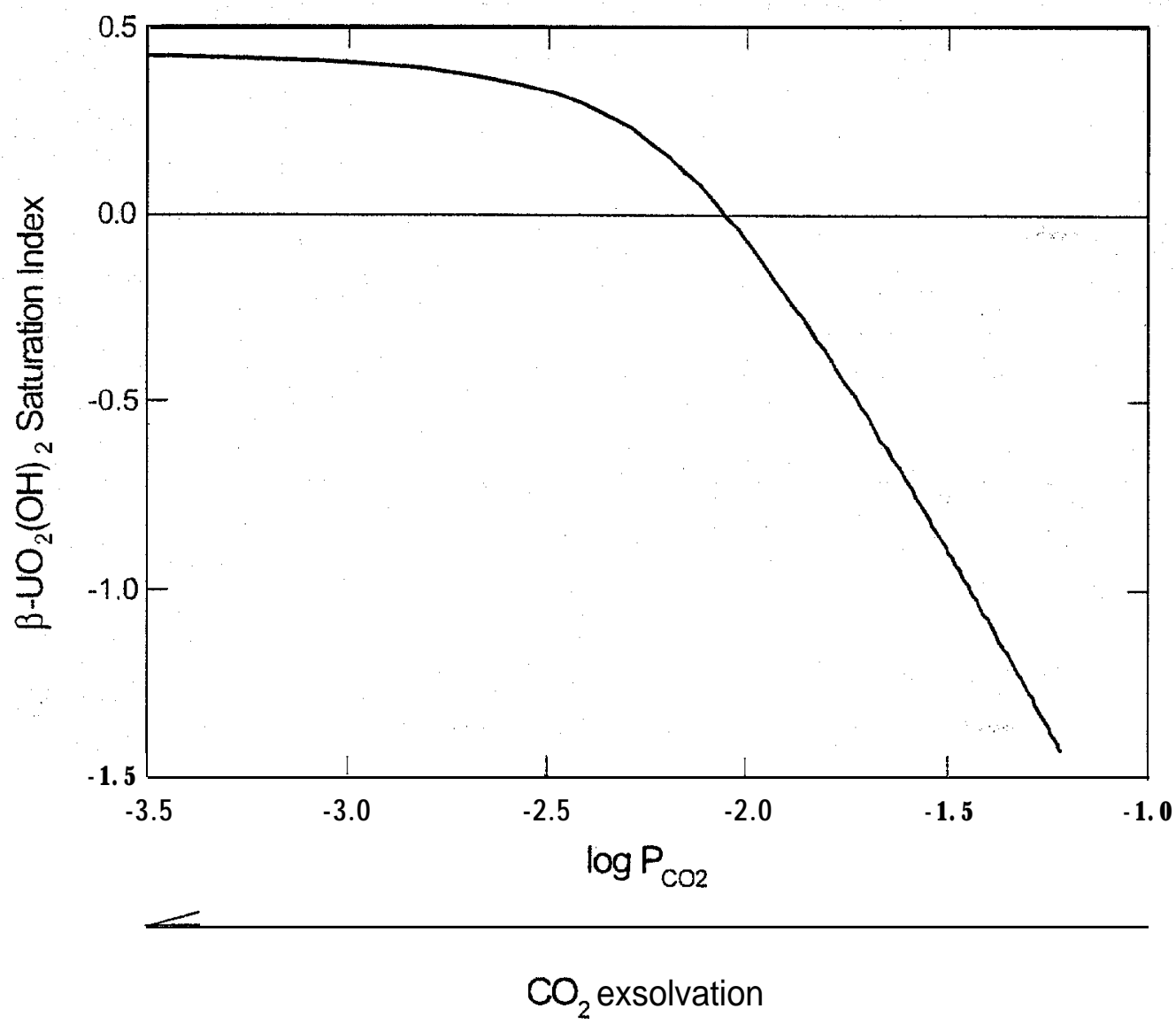

Fig. 3.4. Saturation index with respect to $\boldsymbol{\beta}-\mathrm{UO}_{2}(\mathrm{OH})_{2}$ as a function of $\mathbf{P}_{\mathrm{CO} 2}$ for well $\mathrm{GW}-835$. Manipulations ofgroundwater that lead to loss of $\mathrm{CO}$, from solution may result in the precipitation of $\mathrm{U}$ solids in the absence of microbial dissimilatory $\mathrm{U}$ reduction. 


\subsection{SORPTION}

Sorption to aquifer solids represents another mechanism that can remove $\mathrm{U}$ from solution and delay its migration in the subsurface. Given the impact of hydrolysis and carbonate complexation on U(VI) speciation and saturation state, it seems likely that these processes will also play an important role in governing $\mathrm{U}$ sorption. To investigate these effects, a surface complexation modeling (SCM) approach was adopted using the model developed by Waite et al. (1994) (see Table 3.1). SCM explicitly accounts for changes in solution $\mathrm{pH}$ and ionic strength and is more generally useful than using empirical isotherms whose validity is tightly coupled to the experimental conditions under which they are measured. The model used includes aqueous $\mathrm{U}(\mathrm{W})$-carbonate complexes and the sorption of carbonate and U(VI)-carbónate complexes. Recent X-ray Absorption Fine Structure studies support the importance of considering the latter surface species (Bargar et al., 2000).

Uranium sorption was modeled as a function of $\mathrm{pH}$ and $\mathrm{P}_{\mathrm{CO} 2}$. In these simulations, the equilibrium $\mathrm{pH}$ is varied and all other conditions are held constant. The fraction of $U$ sorbed is plotted versus $\mathrm{pH}$ to generate sorption edges. Modeling results are in general agreement with the experimental observations and modeling results of Waite et al. (1994) and Bamett et al. (2000). In the absence of $\mathrm{CO}_{2}, \mathrm{U}(\mathrm{VI})$ displays cation-type sorption behavior - the fraction sorbed increases with increasing $\mathrm{pH}$ (Fig. 3.5). The fraction sorbed increases sharply over a narrow $\mathrm{pH}$ range and plateaus at $\sim 0.95$ from $\mathrm{pH} 6-8$. At $\mathrm{pH}>8$, the aqueous hydrolysis products exceed the affinity of the surface for uranium and the fraction sorbed decreases. When $\mathrm{PCO},=$ $10^{-3.5}$ or $10^{-2}$, the initial shape of the sorption edge is similar to the no CO, case. Nevertheless, the formation of strong carbonate complexes results in a sharp decline in the fraction sorbed beginning at $\mathrm{pH} 7.5\left(\mathrm{P}_{\mathrm{CO} 2}=\right.$ $\left.10^{-3.5}\right)$ and $\mathrm{pH} 6\left(\mathrm{P}_{\mathrm{CO} 2}=10^{-2}\right)$. At the highest $\mathrm{P}_{\mathrm{CO} 2}$ level examined the maximum fraction of U(VI) sorbed remains below 0.06 .

Another, perhaps more familiar approach is to vary only the initialconcentration of $U$ and hold all other conditions constant. The amount of $\mathrm{U}$ sorbed is plotted versus the equilibrium $\mathrm{U}$ concentration to generate sorption isotherms. Simulated U sorption isotherms were generated using SCM, four different CO, conditions, and $\mathrm{pH}$ either 5.5 or 7 . These $\mathrm{pH}$ values were selected because they bracket the range of most of the $\mathrm{pH}$ measurements from wells showing $\mathrm{U}$ contamination at the FRC site. As expected from the sorption edges, sorption generally increases at the higher $\mathrm{pH}$ (Fig. 3.6). The exception occurring when the partial pressure of $\mathrm{CO}_{2}=10^{-0.757}$. At each $\mathrm{pH}$, uranium sorption decreases with increased $\mathrm{P}_{\mathrm{CO} 2}$, the effect being more apparent at the higher $\mathrm{pH}$. One detail shown in the isotherms is not evident from the sorption edges: the amount of uranium sorbed given an equilibrium aqueous concentration of uranium. For example, at $\mathrm{pH} 5.5$ a water containing $10^{-5} \mathrm{M} \mathrm{U}$ and no carbonate species reflects a sorbed $\mathrm{U}$ concentration of $0.0066 \mathrm{~mole} / \mathrm{kg}$. When the $\mathrm{P}_{\mathrm{Co} 2}$ is $10^{-2}$, the sorbed concentration would be 0.0045 mole $/ \mathrm{kg}$ - a decrease of $32 \%$. 


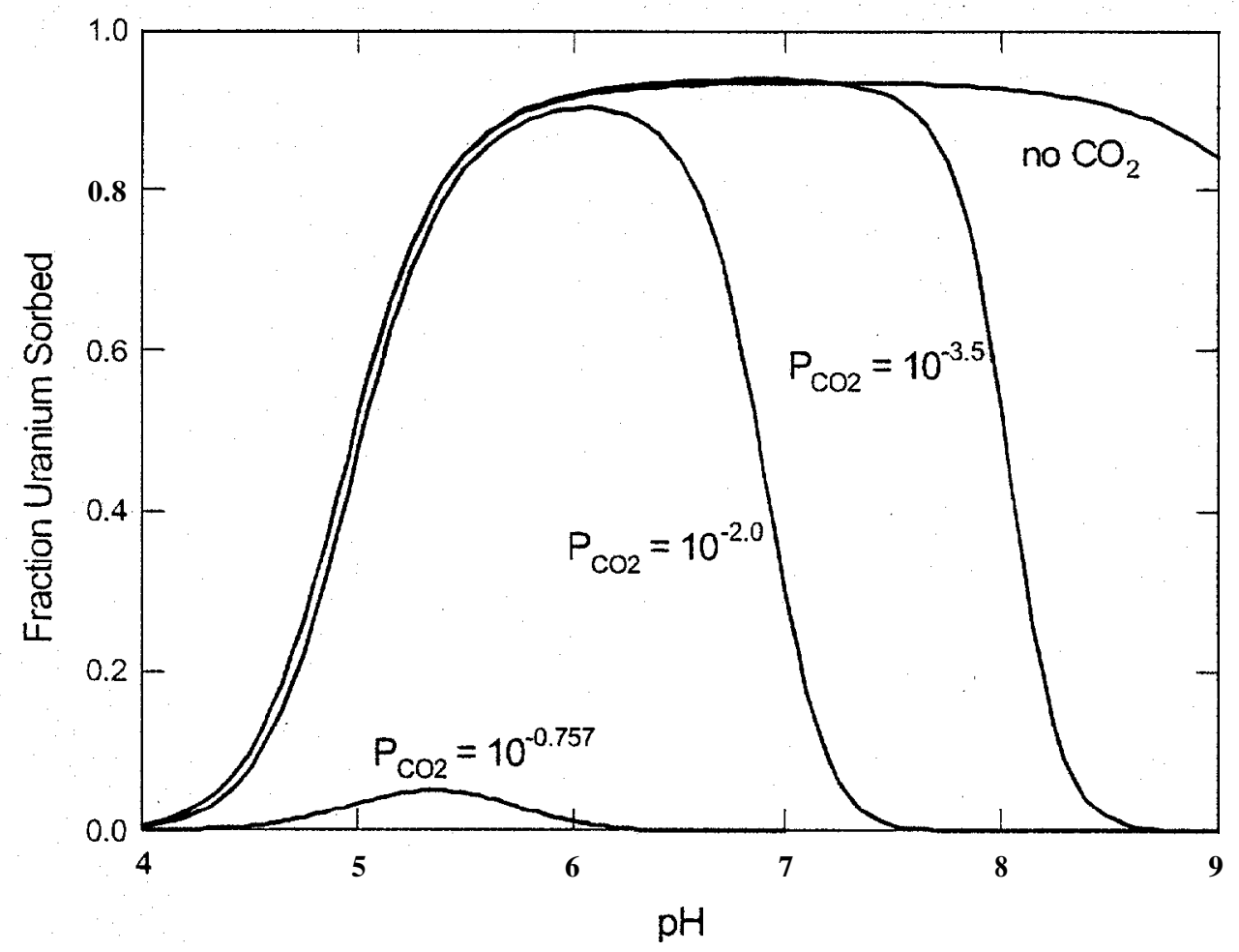

Fig. 3.5. Fraction $U(V)$ ) sorbed to solid phase as a function of $\mathbf{p H}$ and $\mathbf{P}_{\mathrm{coz}} \cdot \mathrm{U}_{\mathrm{ror}}=10^{-5} \mathrm{M}, \mathbf{I}=\mathbf{0 . 2}$. 


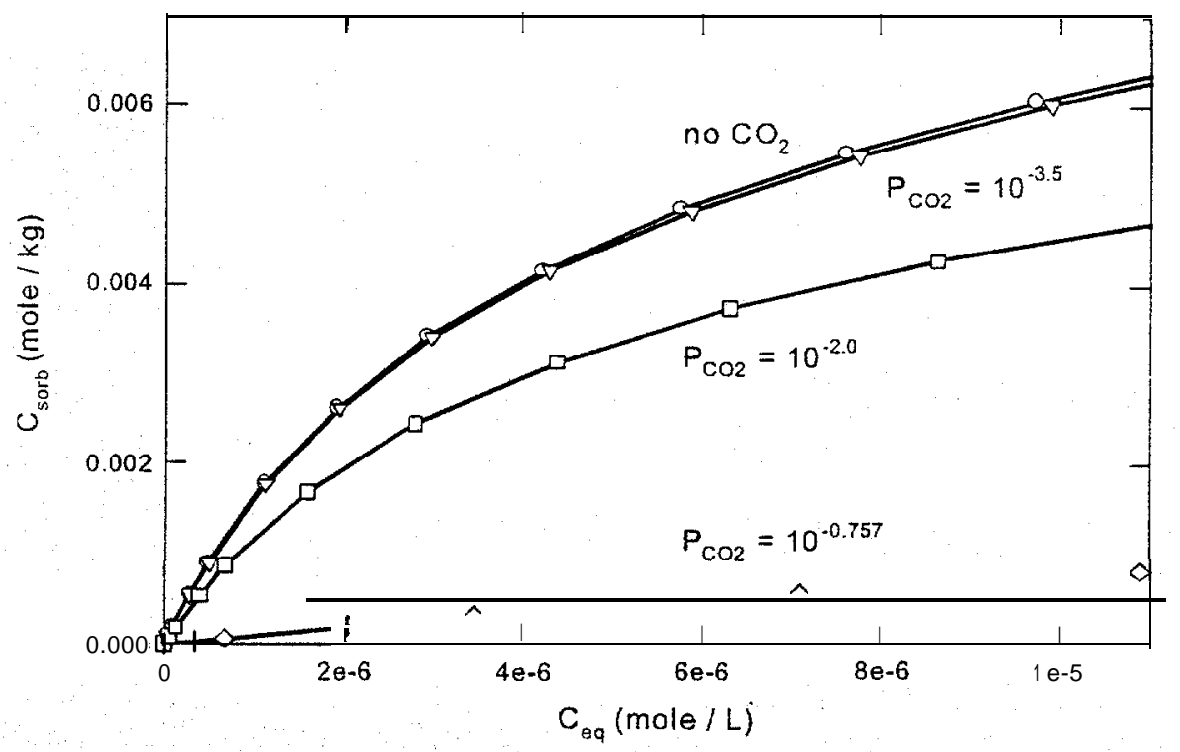

(A)

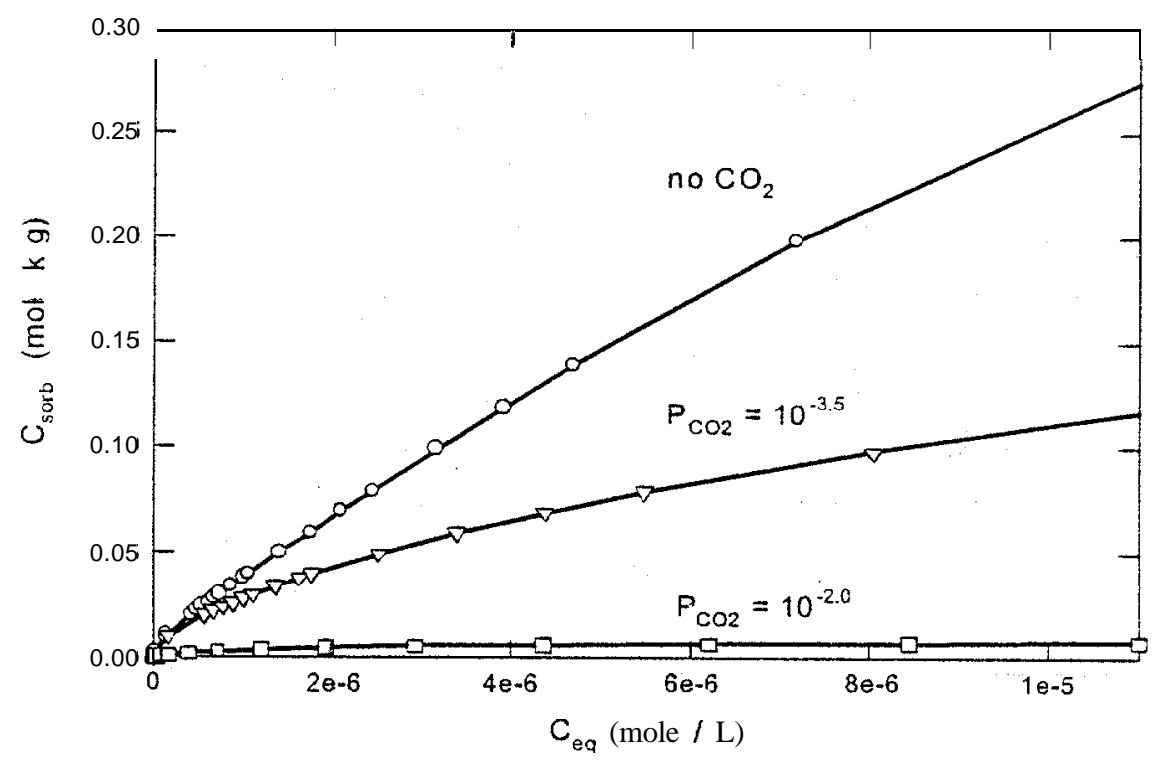

(B)

Fig. 3.6. Uranium sorption isotherms at different $\mathbf{P}_{\mathrm{CO2}}$ levels using a surface complexation model approach. Ionic strength $=0.2 \mathrm{M},(\mathrm{A}) \mathrm{pH} 5.5$, and (B) $\mathrm{pH} 7.0$. At $\mathrm{pH} 7$ and $\mathrm{P}_{\mathrm{CO} 2}=10^{-1.757}$ there is no $\mathrm{U}$ sorption. 


\subsection{TRANSPORT}

Aqueous complexationreactions have a demonstrable effect on U(VI) solubility and sorption. To explore how these reactions might impact uranium movement in groundwater, transport simulations were run that incorporated the processes introduced above (hydrolysis, carbonate complexation, surface complexation model of adsorption). The simulations used a one-dimensional model of advective-dispersive transport assuming homogeneous, isotropic media and the $\mathrm{pH}$ was held constant at $7, \mathrm{U}_{\mathrm{TOT}}=10^{-5} \mathrm{M}$, and $\mathrm{I}=0.2$. These simulations were not meant to match observed data for U(VI) transport through saprolites (e.g., Barnett et a I., 2000) but were intended to illustrate the influence of aqueous chemistry on transport.

Results of the simulations are presented as breakthrough curves in which the relative concentration of the solute ( $=$ concentration in the sample divided by concentration in the influent solution) is plotted versus dimensionless time expressed as pore volumes. We define the uranium retardation $(\mathrm{R})$ as the time at which the relative concentration of uranium reaches $50 \%$ of its influent concentration relative to that of an ideal nonreactive tracer. When no CO, is present in the system $\mathrm{U}(\mathrm{VI})$ transport shows substantial delay and $\mathrm{R}=34$ (Table 3.2, Fig. 3.7); The delayed transport of $\mathrm{U}$ is a result of the accumulation of mass on the solid phase via sorption. Because sorption is modeled as a reversible equilibrium process, the mass stored on the solid phase is released when the pulse is turned off and U-free water passes through the column. U(VI) desorbs from the surface and continues to wash out for an extended time contributing to the tailing behavior seen in the breakthrough curves. As the partial pressure of $\mathrm{CO}$, increases, the formation of uranyl-carbonate complexes decreases uranium retention on the solid phase and uranium transport is more rapid. When $\mathrm{P}_{\mathrm{CO} 2}$ $=10^{-1.757}$ the uranium breakthrough curve is coincident with the nonreactive tracer.

A comprehensive description of the environmental chemistry of $U$ and the actinide elements is beyond the scope of this brief study. Salient aspects that are applicable to work at the FRC have been highlighted and may serve as an entry into additional study for interested readers.

Table 3.2. Influence of $P_{\mathrm{CO} 2}$ on U(V) transport as indicated by $U$ retardation factor.

\begin{tabular}{|c|c|c|c|}
\hline \multicolumn{3}{|c|}{ Uranium Retardation $\left(R=\right.$ time when $\left.C / C_{0}=0.5\right)$ Relative to Nonreactive Tracer } \\
\hline No co, & $\mathrm{P}_{\mathrm{CO}:}=10^{-3.5}$ & $\mathrm{P}_{\mathrm{CO} 2}=10^{-2.0}$ & $\mathrm{P}_{\mathrm{CO} 2}=10^{-0} 757$ \\
\hline 34.1 & 16.6 & 2.2 & $\mathrm{I} .0$ \\
\hline
\end{tabular}




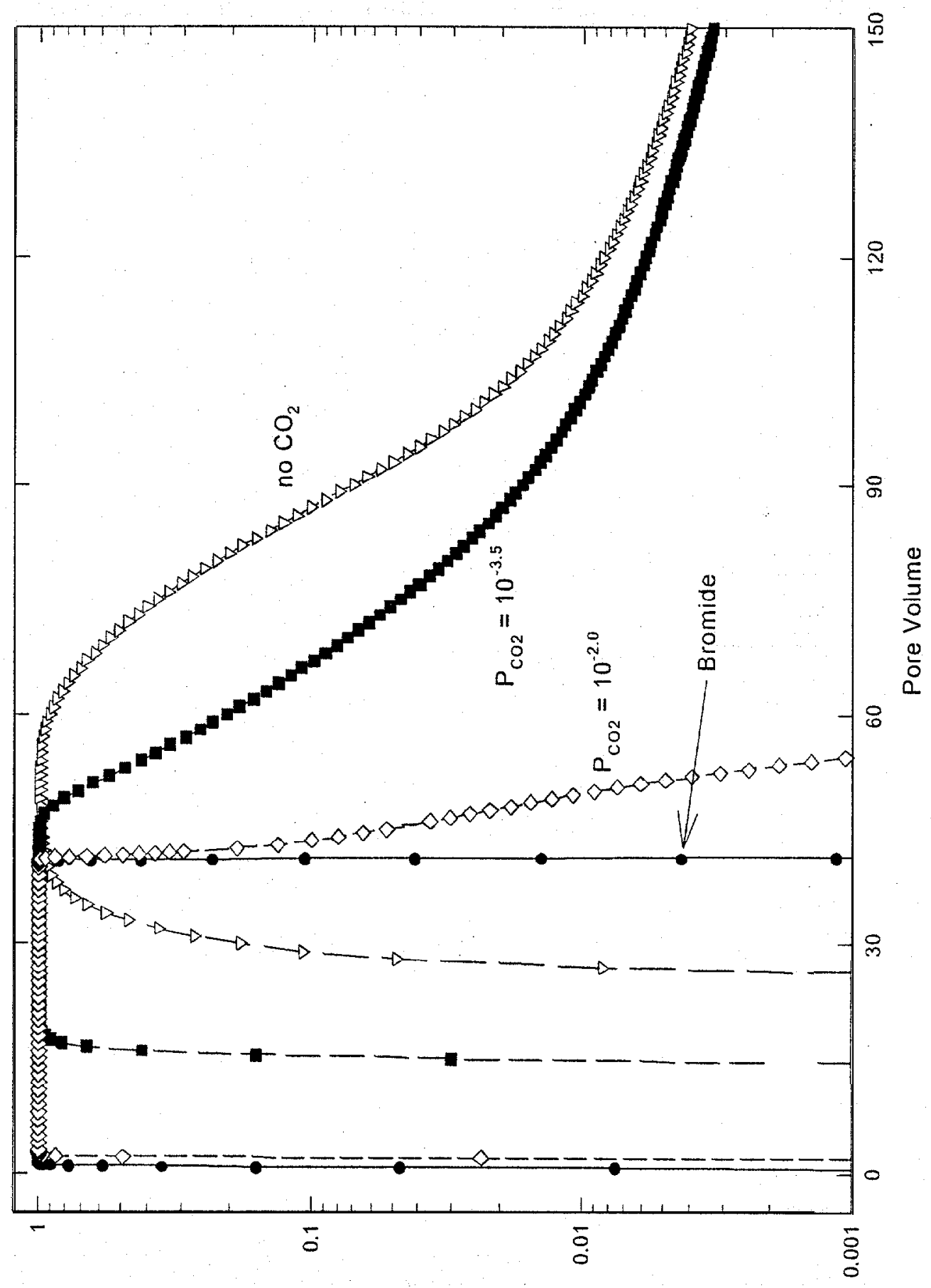

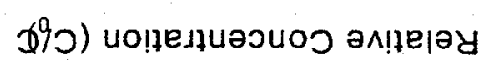

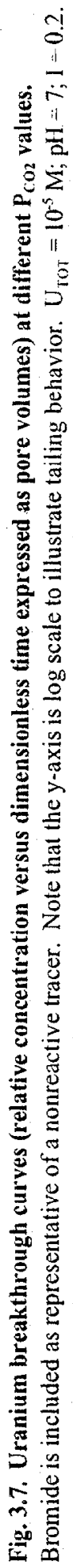




\section{REFERENCES}

Bargar, JR, R Reitmeyer, JL Lenhart, JA Davis. 2000. Characterization of U(VI)-carbonato ternary complexes on hematite: EXAFS and electrophoretic mobility measurements. Geochim Cosmochim Acta. 64:2737-2749.

Barnett, MO, PM Jardine, SC Brooks, and HM Selim. 2000. Adsorption and transport of uranium(VI) in subsurface media. Soil Sci. Soc. Am. J. 64:908-917.

Grenthe, I, J Fuger, RJM Konings, RJ Lemire, AB Muller, CNT Cregu, and H Wanner. 1992. Chemical Thermodynamics of Uranium. North-Holland.

Jeter IW, and JM Napier. Chemical Analysis of the S-3 Disposal Ponds (April, 1978). Y/DA-7794. Union Carbide Corporation. 1978.

Lee, SY, LK Hyder, and PD Alley. 1987. Mineralogical characterization of selected shales in suuport of nuclear waste repository studies. Progress Report. ORNL/TM- 10567.

Luo, S, TL Ku, R Roback, M Murrell, TL McLing. 2000. In-situ radionuclide transport and preferential groundwater flows at INEEL (Idaho): Decay series disequilibrium studies. Geochim. Cosmochim. Acta. 64:867-881.

The Chemical and Radiological Characterization of the S-3 Ponds. Report Y/MA-6400. Union Carbide Corporation. 1983.

Waite, TD, JA Davis, TE Payne, GA Waychunas, and N Xu. 1994. Uranium(VI) adsorption to ferrihydrite: Application of a surface complexation model. Geochim Cosmochim Acta. 58:5465-5478. 